\title{
Tinnitus; an Index of Noise Pollution amongst Church Worshippers in Port Harcourt Metropolis
}

\author{
Matilda Ibekwe \\ Department of Ear, nose and Throat Surgery, Nigeria
}

Submission: December 04, 2018; Published: December 13, 2018

*Corresponding author: Matilda Ibekwe, Department of Ear, nose and Throat Surgery, Nigeria

\begin{abstract}
Background: In this region, Christians constitute the majority of the population and as such most attend church at least once in a week. In recent times church music has changed from quiet hymns to very loud music with the full works. This obtains both in the orthodox and Pentecostal churches. The worshippers therefore are often exposed to very loud sounds without wearing protective hearing devices, hence may not be spared the attendant consequences. The aim of this study therefore is to determine the effect of loud music on the ears of worshippers in the churches, using tinnitus as an index.

Patients and Method: This is a quantitative descriptive study with data obtained by a self-administered questionnaire that was distributed in four randomly selected worship centers within Port Harcourt metropolis; two Pentecostal, one Protestant and one Catholic within a three month period; December 2017 to February 2018. Port Harcourt is the capital of Rivers state and majorly consists of Christian population. It has numerous number of churches scattered all over the metropolis. Worshippers that have been attending the said churches that gave their consent were included while first time attendees were excluded as well as those with previous ear problems prior to this study. Worshippers with discharging ears of any kind were excluded. A sound level meter by Audio control (23MB downloaded from Android play store on Huawei mobile) was also used to determine the average sound level during services in these worship centers. Ethical approval for the study was obtained from the hospital ethical committee. Results were analyzed with SPSS version 20 and presented in simple statistical tables.
\end{abstract}

\section{Introduction}

Tinnitus is defined as perception of sound in the absence of an external stimuli [1]. it can coexist with hearing loss as well as be noise induced. Tinnitus can be a transient sensation in which case it ceases spontaneously lasting just few seconds. It can also be permanent as such affecting the quality of life and interfering with daily life activities [2]. Noise exposure is the commonest cause of tinnitus [3]. According to WHO, noise ranks second in disease causing pollution in the world [4] and tinnitus is the 3rd worst symptom affecting humans exceeded only by intense and intractable pains and dizziness [5]. About 15-20\% of world population suffers from tinnitus and in about $25 \%$ of this affected population, it interferes with daily activity [6]. Though there is presently designed programs and regulations on occupational exposure to noise, there are little or no regulations for exposure to recreational or leisure noise. There are numerous sources of leisure noise and music is prominent among these [7]. Music in discos routinely exceed 90dBA [8], the sound levels in these places can be very high, causing tinnitus and temporary hearing impairment [9]. Exposures to noise levels up to $90 \mathrm{~dB}$ frequently causes the hair cells especially the outer hair cells of the inner ear to degenerate during such exposures [10]. In addition to the loudness, the duration of exposure to the noise also determines the safety and permissibility [11].
The more intense the sound and longer exposure, the more the damage to the hair cells [12]. Sound pressure levels (SPL) in churches can be high, in Brazil in four hour worship; a level of $85 \mathrm{~dB}$ has been recorded. The worshippers including their religious leaders are exposed to health hazards during such church services from high sound levels that can lead to noise induced hearing loss [13]. The high levels therefore compare to the SPL found in music studios, industrial environments like oil rigs, high noise recreational environment such as night clubs $[12,13]$. It is also of note that young adults expose themselves to high levels of noise from personal listening devices, attending night clubs and other loud leisure noise because they are not aware of the import of such exposures and the resulting tinnitus. About $89.5 \%$ of young adults had transient tinnitus after exposure to excessive noise [14]. It is known that intermittent tinnitus is related to excessive noise exposure[14] and the onset of tinnitus could be due to exposure to such excessive noise [15]. In Nigeria, there are numerous worship centers in the capital cities [16]. with the attendant noise pollution. In addition, these church buildings because often are built without consideration to acoustics become closed places where sounds are easily propagated and therefore high risks in producing noise induced hearing impairment [17]. Therefore, a regulation was put in place by the National environmental noise 


\section{Global Journal of Otolaryngology}

standard and regulations enforcement Agency that the maximum permissible noise level in worship centers should not exceed $75 \mathrm{~dB}$ [18] There is little work on effect of church music on hearing in our environment. This study therefore is aimed at finding effect of the noise levels in our churches on the worshippers using tinnitus as an index.

Results

Table 1: Socio-demographics characteristics of church worshippers.

\begin{tabular}{|c|c|c|}
\hline Variables $(\mathrm{N}=94)$ & Frequency & Percentage (\%) \\
\hline \multicolumn{3}{|c|}{ Age category } \\
\hline$<15$ years & 4 & 4.3 \\
\hline $15-24$ years & 12 & 12.8 \\
\hline $25-34$ years & 22 & 23.4 \\
\hline $35-44$ years & 22 & 23.4 \\
\hline $45-54$ years & 8 & 8.5 \\
\hline $55-64$ years & 18 & 19.1 \\
\hline 65 and above & 8 & 8.5 \\
\hline \multicolumn{3}{|c|}{ Sex } \\
\hline Male & 54 & 57.4 \\
\hline Female & 40 & 42.6 \\
\hline \multicolumn{3}{|c|}{ Denomination } \\
\hline Catholic & 80 & 85.1 \\
\hline Protestant & 2 & 2.1 \\
\hline Pentecostal & 12 & 12.8 \\
\hline
\end{tabular}

Table 2: church-related characteristics of worshipper.

\begin{tabular}{|c|c|c|}
\hline Variables $(\mathrm{N}=94)$ & Frequency & Percentage (\%) \\
\hline \multicolumn{3}{|c|}{ Frequency of church worship sessions } \\
\hline Once a week & 16 & 17 \\
\hline Twice a week & 32 & 34 \\
\hline Thrice a week & 18 & 19.1 \\
\hline$>3$ times a week & 28 & 29.8 \\
\hline \multicolumn{3}{|c|}{ How long worshipers has been in church } \\
\hline$<3$ months & 6 & 6.4 \\
\hline $3-6$ months & 6 & 6.4 \\
\hline $7-12$ months & 6 & 6.4 \\
\hline $1-5$ years & 18 & 19.1 \\
\hline$>5$ years & 58 & 61.7 \\
\hline \multicolumn{3}{|c|}{ Loudness of music during church session } \\
\hline Loud & 46 & 48.9 \\
\hline Very loud & 34 & 36.2 \\
\hline Extremely loud & 14 & 14.9 \\
\hline \multicolumn{3}{|c|}{ Proximity of worshipers to loudspeaker } \\
\hline Close & 26 & 27.7 \\
\hline Not so close & 54 & 57.4 \\
\hline Far & 14 & 14.9 \\
\hline Variables ( $N=72$ ) & Frequency & Percentage (\%) \\
\hline
\end{tabular}

Table 3: church-related characteristics of worshipper.

\begin{tabular}{|c|c|c|}
\hline Variables $(\mathrm{N}=72)$ & Frequency & Percentage (\%) \\
\hline \multicolumn{3}{|c|}{ Frequency of tinnitus } \\
\hline Once per month & 26 & 36.1 \\
\hline Twice per month & 16 & 22.2 \\
\hline Thrice per month & 12 & 16.7 \\
\hline 4 times per month & 8 & 11.1 \\
\hline 5 and above & 10 & 13.9 \\
\hline \multicolumn{3}{|c|}{ Tinnitus stopped spontaneously } \\
\hline Yes & 68 & 94.4 \\
\hline No & 4 & 5.6 \\
\hline \multicolumn{3}{|l|}{$\begin{array}{l}\text { Duration tinnitus } \\
\text { stopped }\end{array}$} \\
\hline Within 24 hours & 48 & 66.7 \\
\hline Within a week & 22 & 30.6 \\
\hline Has not stopped & 2 & 2.8 \\
\hline \multicolumn{3}{|c|}{ Same hearing after tinnitus stopped } \\
\hline Yes & 44 & 55.6 \\
\hline No & 32 & 44.8 \\
\hline \multicolumn{3}{|l|}{$\begin{array}{l}\text { See doctor for } \\
\text { tinnitus }\end{array}$} \\
\hline Yes & 16 & 22.5 \\
\hline No & 56 & 77.8 \\
\hline
\end{tabular}

Table 4: Socio-demographic characteristics vs tinnitus in church worshippers.

\begin{tabular}{|c|c|c|c|}
\hline \multirow[t]{2}{*}{ Variables } & \multicolumn{2}{|c|}{ Tinnitus } & \multirow{2}{*}{$\begin{array}{c}\text { Total } N=94 \mathrm{n} \\
(\%)\end{array}$} \\
\hline & Yes $N=72$ n (\%) & No $\mathrm{N}=22$ n (\%) & \\
\hline \multicolumn{4}{|c|}{ Age category } \\
\hline$<15$ years & $0(0.0)$ & $4(100.0)$ & $4(100.0)$ \\
\hline $15-24$ years & $12(100.0)$ & $0(0.0)$ & $12(100.0)$ \\
\hline $25-34$ years & $10(45.5)$ & $12(54.5)$ & $22(100.0)$ \\
\hline 35 - 44 years & $16(72.7)$ & $6(27.3)$ & $22(100.0)$ \\
\hline $45-54$ years & $8(100.0)$ & $0(0.0)$ & $8(100.0)$ \\
\hline $55-64$ years & $18(100.0)$ & $0(0.0)$ & $18(100.0)$ \\
\hline 65 and above & $8(100.0)$ & $0(0.0)$ & $8(100.0)$ \\
\hline \multicolumn{4}{|c|}{ Fisher's exact test $=35.151 ; \mathrm{p}$-value $=0.0001^{*}$} \\
\hline \multicolumn{4}{|l|}{ Sex } \\
\hline Male & $44(81.5)$ & $10(18.5)$ & $54(100.0)$ \\
\hline Female & $28(70.0)$ & $12(30.0)$ & $40(100.0)$ \\
\hline \multicolumn{4}{|c|}{ Chi-square $=1.690 ; \mathrm{p}$-value $=0.194$} \\
\hline \multicolumn{4}{|c|}{ Denomination } \\
\hline Catholic & $58(72.5)$ & $22(27.5)$ & $80(100.0)$ \\
\hline Protestant & $2(100.0)$ & $0(0.0)$ & $2(100.0)$ \\
\hline Pentecostal & $12(100.0)$ & $0(0.0)$ & $12(100.0)$ \\
\hline
\end{tabular}

*statistically significant 


\section{Global Journal of Otolaryngology}

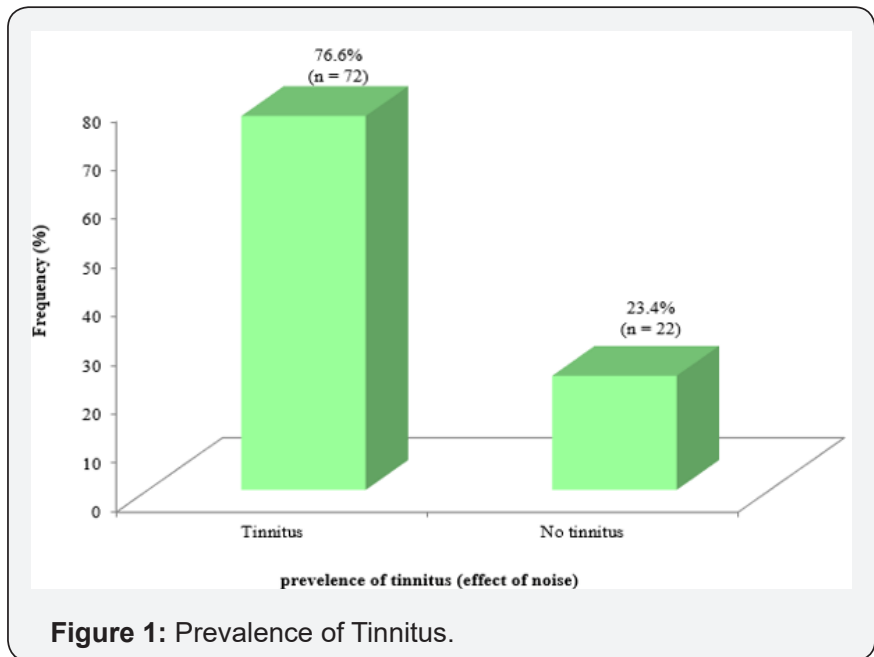

There were ninety four worshippers, $57.4 \%$ males and $42.6 \%$ females. The catholic denomination comprised $85.1 \%$ while Pentecostal which is the least, made up $12.8 \%$. The average sound level is also highest in the Pentecostal and catholic churches 98.4dBA and 98.3 dBA respectively while it is lowest in the protestant church $87.6 \mathrm{dBA}$. The age 25-44years were more affected with $22.4 \%$ (Tables $1 \& 2$ ). Tinnitus was present in $76.6 \%$ of the respondents, (Figure 1). Majority of the respondents has been worshippers for more than $5 y r s ; 61.7 \%$. About $48.9 \%$ found the music loud while $14.9 \%$ found it extremely loud, Table 3. Incidentally $59.6 \%$ of these worshippers are aware of the effect of noise on their hearing. In the majority $66.7 \%$ the tinnitus stopped within 24 hours while in $30.6 \%$ it lasted up to a week and in $2.8 \%$ it did not cease. The hearing was not the same after the tinnitus in $44.8 \%$, (Table 3 ) When the sociodemographic characteristics are considered there is statistical significance of tinnitus with age distribution; p-value of 0.0001 (Table 4). In terms of denomination, catholic denomination had $72.5 \%$ of worshippers with tinnitus while the rest all had $100 \%$ but this difference is not statistically significant. There is however significant chances of developing tinnitus the closer the worshippers sit to the loud speakers. The length of time the worshipper has been attending church as well as the frequency is significant in the developing of tinnitus (Tables 5 \& 6).

Table 5: Church-related characteristics vs tinnitus in church worshippers.

\begin{tabular}{|c|c|c|c|}
\hline \multirow[t]{2}{*}{ Variables } & \multicolumn{2}{|c|}{ Tinnitus } & \multirow[t]{2}{*}{ Total $\mathbf{N}=94$ n (\%) } \\
\hline & Yes $\mathrm{N}=72 \mathrm{n}(\%)$ & No $\mathrm{N}=22 \mathrm{n}(\%)$ & \\
\hline \multicolumn{4}{|c|}{ How long worshippers have been attending church } \\
\hline$<3$ months & $6(100.0)$ & $0(0.0)$ & $6(100.0)$ \\
\hline $3-6$ months & $2(33.3)$ & $4(66.7)$ & $6(100.0)$ \\
\hline $7-12$ months & 69100.00 & $0(0.0)$ & $6(100.0)$ \\
\hline $1-5$ years & $14(77.8)$ & $4(22.2)$ & $18(100.0)$ \\
\hline$>5$ years & $44(75.9)$ & $14(24.1)$ & $58(100.0)$ \\
\hline \multicolumn{4}{|c|}{ Fisher's exact test $=8.000 ; p$-value $=0.060$} \\
\hline \multicolumn{4}{|c|}{ Frequency of church worship } \\
\hline Once a week & $14(87.5)$ & $2(12.5)$ & $16(100.0)$ \\
\hline Twice a week & $24(75.0)$ & $8(25.0)$ & $32(100.0)$ \\
\hline Thrice a week & $16(88.9)$ & $2(11.1)$ & $18(100.0)$ \\
\hline$>3$ times a week & $18(64.3)$ & $10(35.7)$ & $28(100.0)$ \\
\hline \multicolumn{4}{|c|}{ Fisher's exact test $=4.596 ; \mathrm{p}$-value $=0.200$} \\
\hline \multicolumn{4}{|c|}{ Loudness of music during church session } \\
\hline Loud & $32(69.6)$ & $14(30.4)$ & $46(100.0)$ \\
\hline Very loud & $26(76.5)$ & $8(23.5)$ & $34(100.0)$ \\
\hline Extremely loud & $14(100.0)$ & $0(0.0)$ & $14(100.0)$ \\
\hline \multicolumn{4}{|c|}{ Chi-square $=5.546 ; p$-value $=0.062$} \\
\hline \multicolumn{4}{|c|}{ Proximity to loudspeaker } \\
\hline Close & $24(92.3)$ & $2(7.7)$ & $26(100.0)$ \\
\hline Not so close & $42(77.8)$ & $12(22.2)$ & $54(100.0)$ \\
\hline Far & $6(42.9)$ & $8(57.1)$ & $14(100.0)$ \\
\hline \multicolumn{4}{|c|}{ Chi-square $=12.512 ; \mathrm{p}$-value $=0.002^{*}$} \\
\hline
\end{tabular}

*statistically significant. 


\section{Global Journal of Otolaryngology}

Table 6: Church related characteristics versus tinnitus awareness in worshippers.

\begin{tabular}{|c|c|c|c|}
\hline \multirow[t]{2}{*}{ Variables } & \multicolumn{2}{|c|}{ Awareness of effect of noise } & \multirow[t]{2}{*}{ Total $\mathbf{N}=94 \mathrm{n}(\%)$} \\
\hline & Total N = 94 n (\%) & Aware N=56 n (\%) & \\
\hline \multicolumn{4}{|c|}{ How long worshippers have been attending church } \\
\hline$<3$ months & $2(33.3)$ & $4(66.7)$ & $6(100.0)$ \\
\hline $3-6$ months & $6(100.0)$ & $0(0.0)$ & $6(100.0)$ \\
\hline 7 - 12 months & $0(0.0)$ & $6(100.0)$ & $6(100.0)$ \\
\hline $1-5$ years & $8(44.4)$ & $10(55.6)$ & $18(100.0)$ \\
\hline$>5$ years & $40(69.0)$ & $18(31.0)$ & $58(100.0)$ \\
\hline \multicolumn{4}{|c|}{ Fisher's exact test $=18.171 ; \mathrm{p}$-value $=0.0001^{*}$} \\
\hline \multicolumn{4}{|c|}{ Frequency of church worship } \\
\hline Once a week & $4(25.0)$ & $12(75.0)$ & $16(100.0)$ \\
\hline Twice a week & $22(68.8)$ & $10(31.2)$ & $32(100.0)$ \\
\hline Thrice a week & $10(55.6)$ & $8(44.4)$ & $18(100.0)$ \\
\hline$>3$ times a week & $20(71.4)$ & $8(28.6)$ & $28(100.0)$ \\
\hline \multicolumn{4}{|c|}{ Chi Square $=10.815 ; p$-value $=0.013^{*}$} \\
\hline \multicolumn{4}{|c|}{ Loudness of music during church session } \\
\hline Loud & $28(60.9)$ & $18(39.1)$ & $46(100.0)$ \\
\hline Very loud & $22(64.7)$ & $12(35.3)$ & $34(100.0)$ \\
\hline Extremely loud & $6(42.9)$ & $8(57.1)$ & $14(100.0)$ \\
\hline \multicolumn{4}{|c|}{ Chi-.square $=2.028 ; \mathrm{p}$-value $=0.363$} \\
\hline \multicolumn{4}{|c|}{ Proximity to loudspeaker } \\
\hline Close & $12(46.2)$ & $14(53.8)$ & $26(100.0)$ \\
\hline Not so close & $32(59.3)$ & $22(40.7)$ & $54(100.0)$ \\
\hline Far & $12(85.7)$ & $2(14.3)$ & $14(100.0)$ \\
\hline \multicolumn{4}{|c|}{ Chi-square $=5.919 ; \mathrm{p}$-value $=0.052$} \\
\hline
\end{tabular}

\section{Discussion}

This study even though it was carried out in three major worship centers in Port Harcourt metropolis, had only 94 members that consented and filled the self - administered questionnaire properly. The catholic denomination constituted the greater percentage $85.1 \%$ of the study while the least was the protestant. We could not deduce an explanation for this. The finding of more males being affected than females is similar to a study in Brazil by Flores et al.[19] The age's 15-44years were the most affected and this constitutes the youth and the work force. Among the respondents, $76.6 \%$ had tinnitus and about $36.1 \%$ has been suffering intermittent tinnitus at least once a month. About $13.9 \%$ have up to more than five episodes in a month. It is important to note that intermittent tinnitus is often as a result of excessive noise exposure [14]. In majority of these $66.7 \%$ there was spontaneous resolution within 24 hours however a good percentage $30.6 \%$ lingered up to a week, but in $2.8 \%$ it did not resolve. It is known that ringing tinnitus is also related to excessive noise [20]. In about $44.8 \%$ of these worshippers their hearing was gradually being affected since it was not the same after the tinnitus. This lays credence to the study that found temporary shifts in threshold of hearing to be insidious [21] Tinnitus was found to be significantly present in almost all the age category. This shows that the risk of deleterious effect of excessive noise exposure in the churches is significant for all ages with a p-value of 0.0001 . The study also shows that from about age 44 years, the risk of developing tinnitus and possible hearing loss on exposure to excessive noise is even greater, $100 \%$ of them developed tinnitus.

The length of time the worshippers had been in church and their frequency of worship when compared with their awareness of effect of the noise on their ear are statistically significant. They tend to be more aware of the effect. In addition, the closer they are to the loud speakers, the more their chances to develop tinnitus. The average sound levels are highest in the Pentecostal church followed closely by the Catholic Church. It is of note that these levels are much higher than the prescribed $75 \mathrm{~dB}$ A by the Nigerian national environmental noise standard and regulation Act [18]. Most times, the worship sessions in these churches last 2-7 hours, yet the noise levels compare to that in some industrial environments. When there is such high intensity of sound, the duration of exposure should be less. This is because the higher the sound and longer the exposure, the more the damage to the hair cells [12]. In such settings, high intense sounds from music has been associated with temporary hearing impairment [22]. There is therefore need to educate the public on the effects or risks of damage to the hearing from exposure to loud sounds from music [23] this is because loud sounds are not that offensive to the ear 
until they reach up to $120 \mathrm{~dB}$ A [24] This could explain why just about $14.9 \%$ only found the noise extremely loud amongst the respondents while $48.9 \%$ found the music often loud and $27.7 \%$ of them sits lose to the loud speakers. It is important to note that tinnitus could be the first symptom of hearing dysfunction [25].

\section{Recommendations}

There is need for education and public enlightenment on the dangers of loud sounds to the ears. Educate the public on the significance of tinnitus and what to do to avoid it. There should be effort at enforcing strict adherence to the law concerning sound levels in worship centers

\section{Conclusion}

The worship sessions in our churches appear to have become too loud as evidenced by the high sound levels. This has begun to affect the ear health of the worshippers with the attendant presence of intermittent tinnitus in majority of them. Public education on this is of great importance.

\section{References}

1. Alam N, Katarkar A, Shah P, Jalvi R, Jain A, et al. (2012) Audiological, psychological and cognitive characteristics of tinnitus sufferers. Indian journal of otology 18(1): 20-23.

2. Henry J A, Dennis K C, Schechter MA (2005) General review of tinnitus :prevalence, mechanisms, effects and management. US National library of medicine 48(5): 1204-1235.

3. Axelsson A, Prasher D ( 2000) Tinnitus induced by occupational and leisure noise. Noise Health2(8): 47-54.

4. World health organization (2001) Occupational and community noise. Geneva, Switzerland: world health organization (fact sheet 258).

5. World health organization (2010) Quantifying environmental health impacts. Burden of disease from environmental noise: quantification of healthy life years lost in Europe. Copenhagen: Regional office for Europe.

6. Atik A (2014) Pathology and treatment of tinnitus: an elusive disease. Indian J Otolaryngology Head Neck Surg 66(1): 1-5.

7. Clark WW (1991) Noise exposure from leisure activities. A review. J Acust Soc Am 90(1): 175-181.

8. Sadhra S, Jackson CA, Ryder T, Brown MJ (2002) Noise exposure and hearing loss among student employees working in university entertainment venues. Ann Occup Hyg 46(5): 455-463.

9. Metternich FU, Brusis T (1999) Acute hearing loss and tinnitus caused by amplified recreational music. Laryngo Orhinootologie 78(11): 614619.
10. Bredberg G (1985) Cellular pattern and nerve supply of the human organ of corti. Acta Otolaryngol suppl 236: 1-135.

11. Hung O, Kerr MJ, Poling GL, Dhar S (2013) Understanding and preventing noise induced hearing loss. Dis Mon 59(4):110-118.

12. World health organization (2015) A review on hearing loss due to recreational exposure to loud sound. Geneva: world health organization : 7-8.

13. Luiz FS, Rogeiro C (2011) Noise exposure levels of priests and worshippers in protestant churches. International journal of occupational safety and ergonomics 17(1): 79-86.

14. Gilles A, Van Hal G, De Ridder D, Wouters K, Van de Heyning P (2013) Epidemiology of noise-induced tinnitus and the attitude and beliefs towards noise and hearing protection in adolescents. PLoS One 8(7):18 .

15. Degeest S, Corthals P, Vinck B, Keppler H (2014) Prevalence and characteritics of tinnitus after leisure noise exposure in young adults. Noise Health 16: 26-33.

16. Akintaro OA (2014) Perceived effects of noise generated by religious houses on the health of the people of Osun state Nigeria. Journal of education and practice 5(19): 91-95.

17. Hammar Richard R (2005) Sound Advice: is your worship too loud? Church law and tax report.

18. Federal Republic of Nigeria official Gazette (2007) National environmental noise standard and regulations enforcement agency Act 2007. Abuja: Federal Republic of Nigeria official Gazette 96(67): $1-21$.

19. Flores LS, Teixeira AR, Rosito LP, Seimetz BM, Dall Igna C (2016) Pitch and loudness from tinnitus in individuals with noise-induced hearing loss. Int Arch.Otorhinolaryngol 20(3): 248-253.

20. Holmes S, Padgham ND (2011)“Ringing in the ears”: Narrative review of tinnitus and its impact. Biological research for Nursing 13(1): 97108.

21. Yassi A, Pollock N, Tran N, Cheang M (1993) Risks to hearing from a rock concert. Can Fam Physician 39: 1045-1050.

22. Opperman DA, Reifman W, Schlauch R, Levine S (2006) Incidence of spontaneous hearing threshold shifts during modern concert performances. Otolaryngology Head Neck Surg 134(4): 667-673.

23. Chung JH, Roches D, Catherine M, Meunier J, Eavey RD (2005) Evaluation of noise-induced hearing loss in young people using a webbased survey technique. Pediatrics 115(4): 861-867.

24. Eggemann C, Koester M, Zorowka P (2002) Hearing loss due to leisure time noise is on the rise. The ear also needs a rest period. MMW Fortschr Med 144(49): 30-33.

25. Boger ME, Barbosa Branco A, Ottoni AC (2009) The noise spectrum influence on noise-induced hearing loss prevalence in workers. Braz J Otorhinolaryngology 75(3): 328-334. 
CDis work is licensed under Creative (c) Commons Attribution 4.0 License BY DOI: 10.19080/GJO.2018.18.555994
Your next submission with Juniper Publishers will reach you the below assets

- Quality Editorial service

- Swift Peer Review

- Reprints availability

- E-prints Service

- Manuscript Podcast for convenient understanding

- Global attainment for your research

- Manuscript accessibility in different formats

( Pdf, E-pub, Full Text, Audio)

- Unceasing customer service

Track the below URL for one-step submission https://juniperpublishers.com/online-submission.php 